\title{
Left atrial appendage stapling during totally thoracoscopic ablation of long-standing lone persistent atrial fibrillation - lessons learnt
}

\author{
Anna Witkowska ${ }^{1}$, Radosław Hugon Smoczyński ${ }^{1}$, Dominik Drobiński ${ }^{1}$, Dariusz Kosior ${ }^{2,3}$, Sławomir Sypuła ${ }^{2}$, \\ Monika Niewińska ${ }^{1}$, Zygmunt Kaliciński ${ }^{1}$, Bartłomiej Szafron ${ }^{1}$, Jarosław Świstowski ${ }^{1}$, Piotr Suwalski ${ }^{1,4}$ \\ ${ }^{1}$ Department of Cardiosurgery, Central Clinical Hospital of the Ministry of Interior, Warsaw \\ ${ }^{2}$ Clinical Department of Noninvasive Cardiology and Arterial Hypertension, Central Clinical Hospital of the Ministry of Interior, Warsaw \\ ${ }^{3}$ Mossakowski Medical Research Center, Polish Academy of Sciencies, Warsaw \\ ${ }^{4}$ Pulaski University of Technology and Humanities, Radom
}

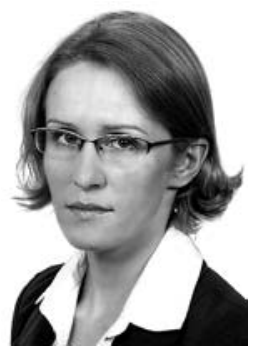

Kardiochirurgia i Torakochirurgia Polska 2013; 10 (4): 330-333

\begin{abstract}
Background: The left atrial appendage (LAA) is considered to be the main site of thrombus formation in patients with atrial fibrillation (AFib). It is found in approximately $1.6-2.1 \%$ of patients undergoing ablation. Many techniques are introduced to reduce the risk of thromboembolic complications in patients with AFib.

Aim of the study: Here we describe the totally thoracoscopic technique of LAA exclusion during ablation for lone persistent atrial fibrillation.

Material and methods: 19 patients (12 men, 7 women) admitted to our department between November 2011 and February 2013 with lone persistent and long-standing persistent AFib underwent totally thoracoscopic ablation with LAA stapling. Mean age, AFib duration, EuroSCORE II, CHA2DS2-VASc score, left atrial dimension and LVEF were 57.8 ( \pm 11 ) years, $52.6 \pm 50$ months, $0.67 \pm 0.2 \%, 1.5 \pm 1.3,41 \pm 63 \mathrm{~mm}$ and $63.7 \pm 6.5 \%$, respectively. One patient (5.8\%) experienced prior stroke. All patients underwent transesophageal echocardiogram before the operation to rule out thrombus in the LAA. LAA exclusion was performed with the novel Tri-Staple stapler (Covidien, Mansfield, USA). Results: All but one patient (95\%) were eligible for LAA stapling. The procedure took only a few minutes. We did not observe early or late bleeding from the stapler line. We had one case of bleeding from the left atrial wall in connection with LAA stapling successfully treated surgically. In transthoracic echocardiography we obtained confirmation of complete LAA exclusion with smooth endocardium. No incidence of stroke/TIA in follow-up was noted. All patients are alive.

Conclusions: In our experience totally thoracoscopic LAA stapling is feasible and safe when done with caution and proper use of the stapler.

Key words: atrial fibrillation, thoracoscopic ablation.
\end{abstract}

\section{Streszczenie}

Wstęp: Najczęstszym miejscem powstawania materiału zatorowo-zakrzepowego u pacjentów z migotaniem przedsionków (AFib) jest uszko lewego przedsionka (LAA). Materiał jest uwidaczniany u ok. 1,6-2,1\% pacjentów poddawanych ablacji. Obecnie rozwijanych jest coraz więcej metod mających na celu redukcję ryzyka wystąpienia powikłań zatorowo-zakrzepowych u pacjentów z AFib.

Cel pracy: W niniejszym artykule opisano całkowicie torakoskopową, mało inwazyjną technikę usuwania LAA z zastosowaniem nowego staplera podczas ablacji samoistnego przetrwałego i przetrwałego długo trwającego migotania przedsionków.

Materiał i metody: 19 pacjentów (12 mężczyzn, 7 kobiet) przyjętych pomiędzy listopadem 2011 a lutym 2013 z samoistnym przetrwałym i przetrwałym długo trwającym AFib zostało poddanych całkowicie torakoskopowej ablacji podłoża arytmii z usunięciem LAA. Średni wiek, czas trwania arytmii, EUROScore II, CHA2DS2-VASc score, wymiar lewego przedsionka i LVEF wyniosły odpowiednio: $57,8 \pm 11$ lat, 52,6 \pm 50 miesięcy, 0,67 $\pm 0,2 \%, 1,5 \pm 1,3,41$ $\pm 63 \mathrm{~mm}$ i $63,7 \pm 6,5 \%$. Jeden pacjent przebył udar mózgu (5,8\%). U wszystkich pacjentów wykonano przedoperacyjne przezprzełykowe badanie echokardiograficzne w celu wykluczenia skrzepliny w LAA. Do usunięcia LAA wykorzystano nowy stapler endoskopowy Tri-Staple (Covidien, Mansfield, USA).

Wyniki: Usunięcie LAA wykonano u 18 pacjentów (95\%). Procedura staplowania trwała kilka minut z wprowadzeniem staplera. Nie stwierdzono wczesnego ani późnego krwawienia z linii staplera. U jednego pacjenta doszło do rozdarcia ściany lewego przedsionka $w$ trakcie zakładania staplera na podstawę LAA skutecznie zaopatrzonego chirurgicznie. W kontrolnym badaniu echokardiograficznym potwierdzono dobry efekt usunięcia LAA z gładką linią endotelium. Nie odnotowano śmiertelności ani udarów w obserwacji wczesnej ani średnioodległej.

Address for correspondence: Anna Witkowska PhD, Department of Cardiosurgery, Central Clinical Hospital of the Ministry of Interior, Wołoska 137, 02-507 Warsaw, Poland, e-mail: vera@rallywitkowscy.pl 


\section{Introduction}

Atrial fibrillation (AFib) is the most prevalent cardiac arrhythmia and its occurrence increases with aging of the general population [1, 2]. Morbidity and economic costs make AFib one of the most important challenges in recent medicine. As pharmacological treatment has poor results, different ablation techniques are developed. In many publications surgical ablation was proved to have superior results in sinus rhythm restoration compared to catheter ablation [2-4]. According to the global trend in minimizing surgical access recently many minimally invasive surgical techniques have been under evaluation [4-6]. Along with the disabling symptoms of AFib, the risk of thromboembolic events dramatically rises. According to the literature in over $90 \%$ the source of embolic material in non-valvular atrial fibrillation is the left atrial appendage (LAA) $[2,7,8]$. This makes LAA exclusion one of the main goals in the treatment of patients with nonvalvular AFib.

\section{Aim of the study}

Here we describe the totally thoracoscopic technique of LAA exclusion during bilateral ablation for lone persistent and long-standing persistent AFib.

\section{Material and methods}

Nineteen patients (12 men, 7 women) admitted to our department between November 2011 and February 2013 with persistent and long-standing persistent atrial fibrillation underwent totally thoracoscopic ablation of arrhythmia with left atrial appendage stapling. Mean age, AFib duration, EuroSCORE II, CHA2DS2-VASc score, left atrial dimension and LVEF were $57.8 \pm 11$ years, $52.6 \pm 50$ months, $0.67 \pm 0.2 \%$, $1.5 \pm 1.3,41 \pm 63 \mathrm{~mm}$ and $63.7 \pm 6.5 \%$, respectively. One patient (5.8\%) experienced prior stroke. All patients underwent transesophageal echocardiography before the operation to rule out thrombus or blood sludge in LAA. Ablation was performed with the ORLab system (AtriCure, Ohio, USA). LAA exclusion was performed as the last step of the procedure using the new Tri-Staple stapler (Covidien, Mansfield, USA).

\section{Results}

No mortality was observed. All but one patient (95\%) were eligible for LAA stapling. The stapler placement and LAA separation take a few minutes. We did not observe early (intraoperative) or late bleeding from the stapler line. There was one case of bleeding from the left atrial wall connected with a tear during LAA stapling successfully treated surgically. In transthoracic echocardiography we obtained confirmation of complete LAA exclusion with smooth endocardium. No incidence of stroke or TIA in follow-up was noted. Good
Wnioski: Całkowicie torakoskopowe usunięcie LAA z zastosowaniem nowego staplera jest skuteczne i bezpieczne przy odpowiednim jego użyciu.

Słowa kluczowe: migotanie przedsionków, ablacja torakoskopowa.

atrial transport function and anatomical results of LAA exclusion in echocardiography were observed in all patients.

\section{Discussion}

Stroke and transient ischemic attack (TIA) are the most devastating complications in patients with atrial fibrillation. Stroke risk rises 5 -fold in presence of AFib and one in five strokes is attributed to this arrhythmia $[1,7,8]$. Strokes associated with AFib are more often fatal (risk of death is doubled), and more devastating in symptoms [1]. Moreover, undiagnosed so-called "silent AFib" can cause cryptogenic strokes [1]. This makes prevention of stroke/TIA one of the most important goals in AFib treatment. Anticoagulation therapy significantly reduces absolute annual risk in all strokes by $2.7 \%$ [9]. However, its introduction is based on presence of risk factors assessed by risk scales such as CHADS2 and CHA2DS2VASc scores, requires regular blood tests and precise adjustment of dosage, and increases the risk of bleeding [1, 9]. As stand-alone AFib also occurs in younger, working patients with no additional risk factors, the problem of AFib-related strokes is even more important. Some authors have reported that over $90 \%$ of thromboembolic material has its origin in the left atrial appendage (LAA) [7]. Moreover, in a recently published study the authors correlated left atrial appendage morphology assessed in magnetic resonance and computed tomography with risk of stroke in patients with AFib [8]. They divided LAA into four types - Chicken Wing, Windsock, Cauliflower and Cactus. According to their results, Chicken Wing LAA morphology is the most prevalent (48\% of their population) and with the least risk of stroke/TIA, but all patients with non-Chicken Wing morphology had strikingly increased risk of thromboembolic events up to $4.6 \%$ (10-fold) [8]. What is even more important, this increased risk was independent from low risk assessed on the above-mentioned scales [8]. Recently there is much interest in LAA occlusion (LAAO) techniques with percutaneous devices such as WATCHMAN, LARIAT, Amplatzer or cardiac plug [10-15]. However, there are concerns about safety and efficacy of LAAO devices mainly connected with dislodgement of the device and complications related to low operator experience [12].

In our department we started a minimally invasive approach in surgical treatment of patients with lone persistent and long-standing persistent atrial fibrillation with totally thoracoscopic access (Fig. 1). In the last stage as prevention of stroke/TIA we perform excision of the left atrial appendage. Therefore we use an endoscopic Endo-GIA stapler with the novel Tri-Staple reloads (Covidien, Mansfield, USA). TriStaple has very good properties in hermetic tissue squeezing with a sealed stapling line. We introduce the stapler through the $6^{\text {th }}$ or $7^{\text {th }}$ intercostal space above the diaphragm. The reload has two arms - the one with staples is longer, massive 


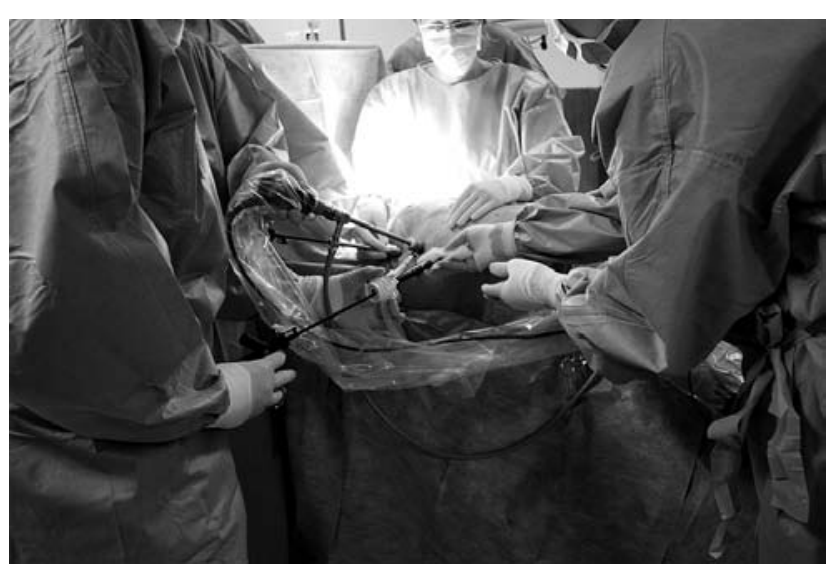

Fig. 1. Thoracoscopic access from right side similar as from left side

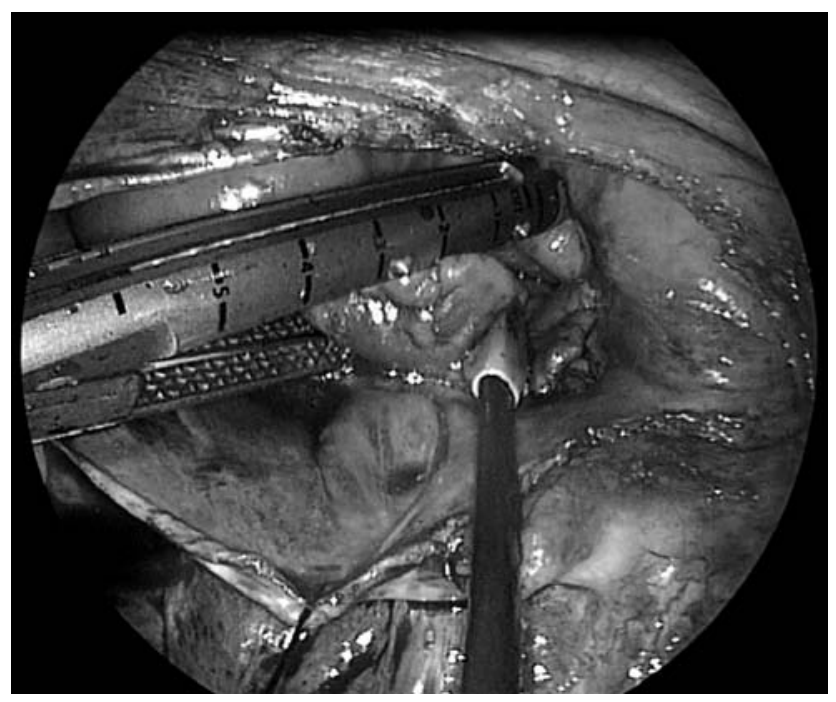

Fig. 2. Grasping the left atrial appendage with stapler arms. Placing still arm beneath and movable arm above the LAA is crucial

and movable, while the second is shorter, flat and still. According to our experience the proper stapler placement with still arm beneath and movable arm above the LAA is crucial (Fig. 2). In such a position the base of the LAA is tightened to the firm flat surface of the still arm under continuous visual control of squeezed tissues (Fig. 3). This procedure takes only a few minutes, and thus does not prolong the operation. In case of incomplete separation of the distal end of the LAA it is feasible to apply a green reload (Fig. 4). However, in such a situation during our procedures the remaining tissue was not the true left atrial wall but just connective and fatty tissue. It is sufficient to use a vascular clip to safely separate the LAA (Fig. 5). In one patient as a result of stapling we observed a massive tear of the left atrial wall just beneath the appendage base which required sewing via sternotomy. After stopping the bleeding we observed a complete, sealed stapler line. In our opinion the injury was caused by rotation of the reload so that the movable, longer arm was downward and while closing the device we pulled up the left atrial wall with the tip of the longer arm, leading to its tension and tear.

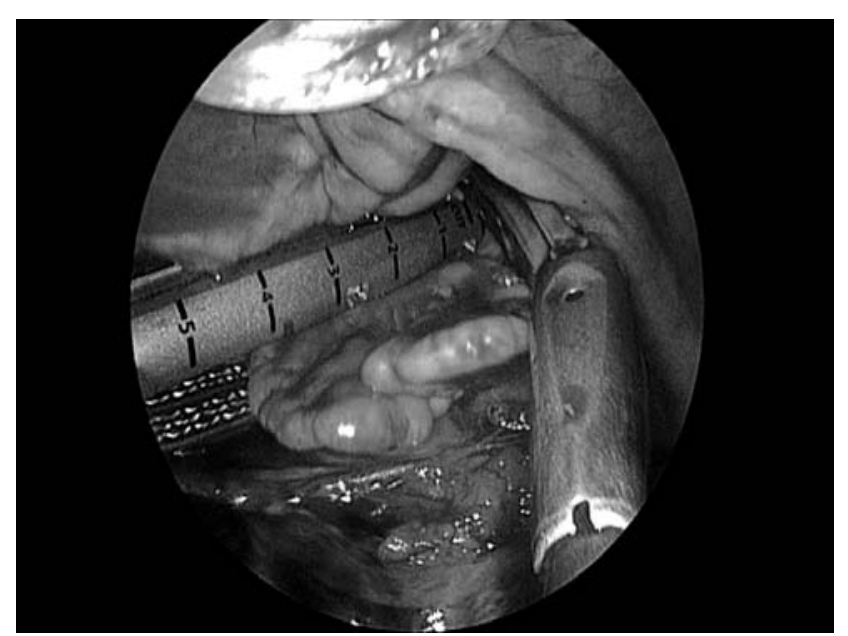

Fig. 3. Visual control of complete grasp of left atrial appendage

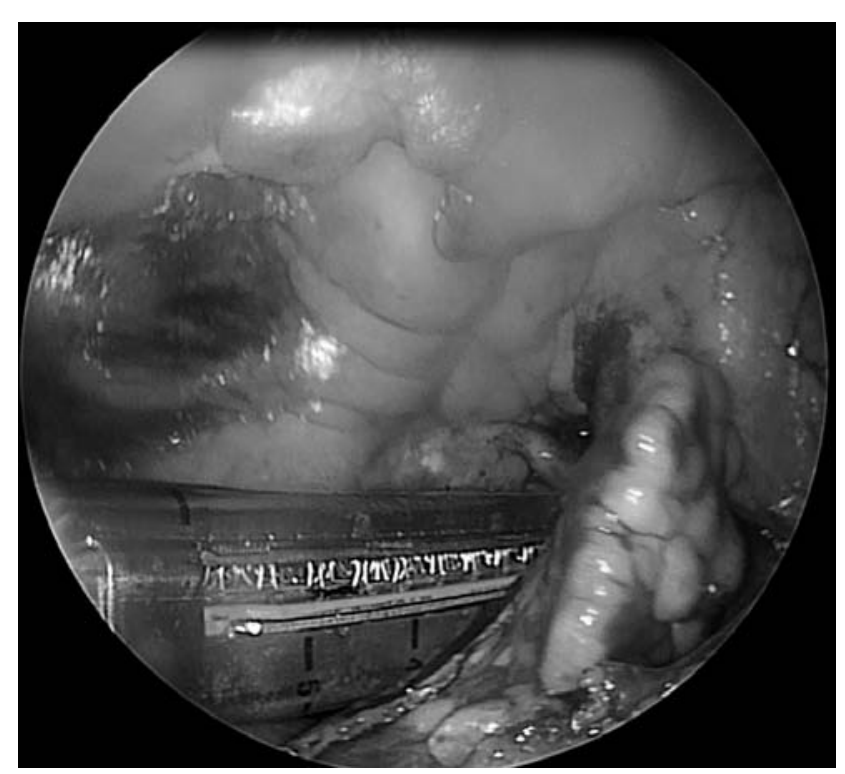

Fig. 4. Additional application of green reload on remaining tissue

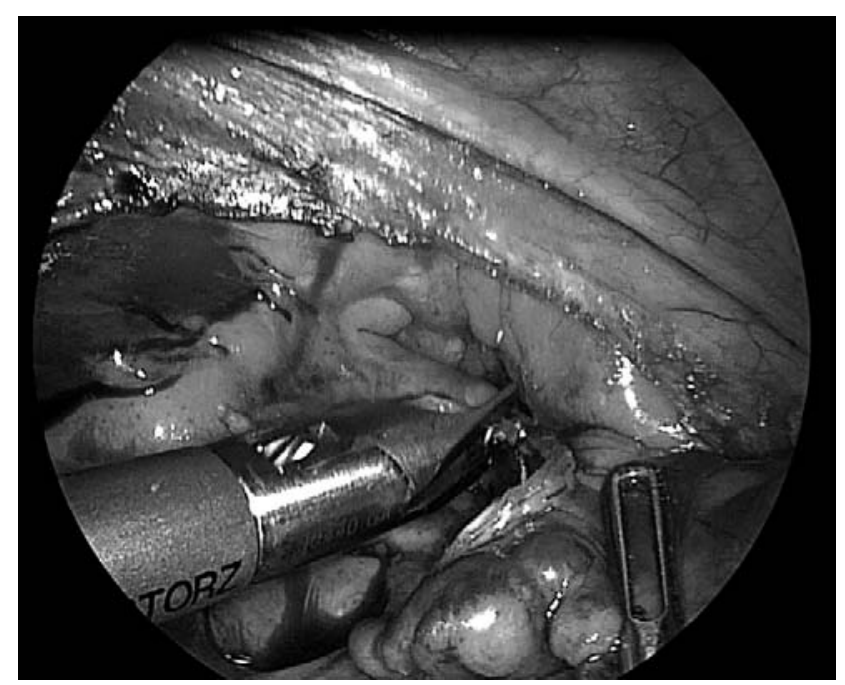

Fig. 5. Additional application of vascular clip on remaining tissue 
After this case we did not reverse the reload, and such a situation has not been repeated. Only one in 19 patients had such a small, flat left atrium that we were not able to grasp it with the stapler arms. Other LA appendages, even small ones but with a defined base, were eligible for safe excision.

\section{Conclusions}

Primary and secondary stroke prevention is crucial in the treatment of patients with all types of atrial fibrillation. As the left atrial appendage is the main site of thrombus formation in this population, we should search for effective and safe methods of its exclusion. In our experience totally thoracoscopic LAA stapling is feasible and safe when done with caution and proper use of the stapler. Further studies including prospective randomized trials in this group of patients are needed.

\section{References}

1. European Heart Rhythm Association; European Association for Cardio-Thoracic Surgery, Camm AJ, Kirchhof P, Lip GY, Schotten U, Savelieva I, Ernst S, Van Gelder IC, Al-Attar N, Hindricks G, Prendergast B, Heidbuchel H, Alfieri O, Angelini A, Atar D, Colonna P, De Caterina R, De Sutter J, Goette A, Gorenek B, Heldal M, Hohloser SH, Kolh P, Le Heuzey JY, Ponikowski P, Rutten FH. Guidelines for the management of atrial fibrillation: the Task Force for the Management of Atrial Fibrillation of the European Society of Cardiology (ESC). Eur Heart J 2010; 31: 2369-2429.

2. Calkins H, Kuck KH, Cappato R, Brugada J, Camm AJ, Chen SA, Crijns HJ, Damiano RJ Jr, Davies DW, DiMarco J, Edgerton J, Ellenbogen K, Ezekowitz MD, Haines DE, Haissaguerre M, Hindricks G, lesaka Y, Jackman W, Jalife J, Jais P, Kalman J, Keane D, Kim YH, Kirchhof P, Klein G, Kottkamp H, Kumagai K, Lindsay BD, Mansour M, Marchlinski FE, McCarthy PM, Mont JL, Morady F, Nademanee K, Nakagawa H, Natale A, Nattel S, Packer DL, Pappone C, Prystowsky E, Raviele A, Reddy V, Ruskin JN, Shemin RJ, Tsao HM, Wilber D. 2012 HRS/EHRA/ECAS expert consensus statement on catheter and surgical ablation of atrial fibrillation: recommendations for patient selection, procedural techniques, patient management and follow-up, definitions, endpoints, and research trial design. J Interv Card Electrophysiol 2012; 33: 171-257.

3. Bauer M, Hetzer R. Video-assisted thoracoscopic surgical treatment of lone atrial fibrillation. Multimed Man Cardiothorac Surg 2009; 1127: 2009 / doi:10.1510/mmcts.2008.003848

4. Pison L, La Meir M, van Opstal J, Blaauw Y, Maessen J, Crijns H.J. Hybrid thoracoscopic surgical and transvenouc catcheter ablation of atrial fibrillation. J Am Coll Cardiol 2012; 60: 54-61.
5. Zembala M.O, Filipiak K, Kowalski O, Boidol J, Sokal A, Lenarczyk R, Niklewski T, Garbacz M, Nadziakiewicz P, Kalarus Z, Zembala M. Minimally invasive hybrid ablation procedure for the treatment of persistent atrial fibrillation: one year results. Kardiol Pol 2012; 70: 819-828.

6. Suwalski P, Suwalski G, Wilimski G, Kochanowski J, Scisło P, Gaca H, Popiel Z, Śledź M, Smolarska-Świtaj J, Suwalski K. Minimally invasive off-pump video-assisted endoscopic surgical pulmonary vein isolation using bipolar radiofrequency ablation - preliminary report. Kardiol Pol 2007; 65: 370-374.

7. Watson T, Shantsila E, Lip GY. Mechanisms of thrombogenesis in atrial fibrillation: Virchow's triad revisited. Lancet 2009; 373: 155-166.

8. Di Biase L, Santangeli P, Anselmino M, Mohanty P, Salvetti I, Gili S, Horton R, Sanchez JE, Bai R, Mohanty S, Pump A, Cereceda Brantes M, Gallinghouse GJ, Burkhardt JD, Cesarani F, Scaglione M, Natale A, Gaita F. Does the left atrial appendage morphology correlate with the risk of stroke in patients with atrial fibrillation? J Am Coll Cardiol 2012; 60: 531-538.

9. Hart RG, Pearce LA, Aguilar MI. Meta-analysis: antithrombotic therapy to prevent stroke in patients who have nonvalvular atrial fibrillation. Ann Intern Med 2007; 146: 857-867.

10. Sievert H, Lesh MD, Trepels T, Omran H, Bartorelli A, Della Bella P, Nakai T, Reisman M, DiMario C, Block P, Kramer P, Fleschenberg D, Krumsdorf U, Scherer D. Percutaneous left atrial appendage transcatheter occlusion to prevent stroke in high-risk patients with atrial fibrillation: early clinical experience. Circulation 2002; 105: 1887-1889.

11. Fountain R, Holmes DR Jr, Hodgson PK, Chandrasekaran K, Van Tassel R, Sick P. Potential applicability and utilization of left atrial appendage occlusion devices in patients with atrial fibrillation. Am Heart J 2006; 152: 720-723.

12. Lip GY, Dagres N, Proclemer A, Svendsen JH, Pison L, Blomstrom-Lundqvist C; Scientific Initiative Committee, European Heart Rhythm Association. Left atrial appendage occlusion for stroke prevention in atrial fibrillation in Europe: results of the European Heart Rhythm Association survey. Europace 2013; 15: 141-143.

13. Reddy VY, Holmes D, Doshi SK, Neuzil P, Kar S. Safety of percutaneous left atrial appendage closure: results from the Watchman Left Atrial Appendage System for Embolic Protection in Patients with AF (PROTECT AF) clinical trial and the Continued Access Registry. Circulation 2011; 123: 417-424.

14. Gangireddy SR, Halperin JL, Fuster V, Reddy VY. Percutaneous left atrial appendage closure for stroke prevention in patients with atrial fibrillation: an assessment of net clinical benefit. Eur Heart J 2012; 33: 2700-2708.

15. Bartus K, Han FT, Bednarek J, Myc J, Kapelak B, Sadowski J, Lelakowski J, Bartus S, Yakubov SJ, Lee RJ. Percutaneous left atrial appendage suture ligation using the LARIAT device in patients with atrial fibrillation: initial clinical experience. J Am Coll Cardiol 2013; 62: 108-118. 